\section{Comparison of the effects of three different Baccaurea angulata whole fruit juice doses on plasma, aorta and liver MDA levels, antioxidant enzymes and total antioxidant capacity}

By: Ibrahim, M (Ibrahim, Muhammad) ${ }^{[1]}$; Mikail, MA (Mikail, Maryam Abimbola) $^{[1]}$; Ahmed, IA (Ahmed, Idris Adewale) ${ }^{[1,5]}$;

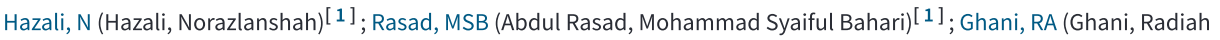
Abdul) $^{[1]}$; Hashim, R (Hashim, Ridzwan) ${ }^{[1]}$; Arief, SJ (Arief, Solachuddin Jahuari) ${ }^{[2]}$; Isa, MLM (Isa, Muhammad Lokman Md) ${ }^{[3]}$; Draman, S (Draman, Samsul) ${ }^{[4]}$

EUROPEAN JOURNAL OF NUTRITION

Volume: 57 Issue: 5 Pages: 1817-1828

DOI: $10.1007 / \mathrm{s} 00394-017-1466-3$

Published: AUG 2018

Document Type: Article

View Journal Impact

\section{Abstract}

Baccaurea angulata (common names: belimbing dayak or belimbing hutan) is a Malaysian underutilized fruit. The preliminary work on B. angulata fruit juice showed that it possesses antioxidant properties. Therefore, further work is needed to confirm the efficacy and proper dosage of $B$. angulata as a potential natural antioxidant. The present study was thus carried out to compare the effects of three different B. angulata whole fruit (WF) juice doses administered at nutritional doses of $0.50,1.00$ and $1.50 \mathrm{ml} / \mathrm{kg} /$ day on plasma, aorta and liver malondialdehyde (MDA) levels, antioxidant enzymes (superoxide dismutase, glutathione peroxidase and catalase) as well as total antioxidant capacity in rabbits fed highcholesterol diet.

Thirty-five male rabbits of New Zealand strain were randomly assigned to seven groups. For 12 weeks, group $\mathrm{CH}$ was fed $1 \%$ cholesterol diet only; group C1 was fed $1 \%$ cholesterol diet and $0.50 \mathrm{ml} / \mathrm{kg} / \mathrm{day} \mathrm{B}$. angulata WF juice; group C2 was fed $1 \%$ cholesterol diet and $1.00 \mathrm{ml} / \mathrm{kg} / \mathrm{day}$ B. angulata WF juice; group C3 was fed $1 \%$ cholesterol diet and $1.50 \mathrm{ml} / \mathrm{kg} / \mathrm{day} \mathrm{B}$. angulata WF juice; group N was fed standard pellet only; group N1 was fed standard pellet and $0.50 \mathrm{ml} / \mathrm{kg} / \mathrm{day} \mathrm{B}$. angulata WF juice; and group N2 was fed standard pellet and $1.00 \mathrm{ml} / \mathrm{kg} /$ day $\mathrm{B}$. angulata WF juice.

The three doses reduced the formation of MDA and enhanced the expression of endogenous antioxidant enzymes. The highest dose used $(1.50 \mathrm{ml} / \mathrm{kg} /$ day) was, however, seen as the most potent.

Higher doses of B. angulata juice exerted better antioxidant activity.

Keywords

Author Keywords: Antioxidant enzymes; Baccaurea angulata; Doses; Malondialdehyde; Underutilized fruit KeyWords Plus: HIGH-FAT DIET; TYPE-2 DIABETES-MELLITUS; INDUCED OXIDATIVE STRESS; CHOLESTEROL-FED RABBITS; HEMATOLOGICAL PARAMETERS; LIPID-PEROXIDATION; RAT ERYTHROCYTES; L. FRUIT; EXTRACT; HYPERCHOLESTEROLEMIA

\section{Author Information}

Reprint Address: Ibrahim, M (reprint author)

+ Int Islamic Univ Malaysia, Kulliyyah Allied HIth Sci, Kuantan Campus, Kuala Lumpur, Malaysia.

\section{Addresses:}

+ [1] Int Islamic Univ Malaysia, Kulliyyah Allied Hlth Sci, Kuantan Campus, Kuala Lumpur, Malaysia

+ [2 ] Int Islamic Univ Malaysia, Kulliyyah Dent, Kuantan Campus, Kuala Lumpur, Malaysia

+ [3 ] Int Islamic Univ Malaysia, Kulliyyah Nursing, Kuantan Campus, Kuala Lumpur, Malaysia

+ [4] Int Islamic Univ Malaysia, Kulliyyah Med, Kuantan Campus, Kuala Lumpur, Malaysia

[5] Lincoln Univ Coll Malaysia, Dept Biotechnol, Fac Sci, Kelana Jaya Campus, Petaling Jaya 47301, Selangor, Malaysia

E-mail Addresses: abumaisarah@iium.edu.my

\section{Citation Network \\ In Web of Science Core Collection}

\section{4}

Times Cited

Create Citation Alert

All Times Cited Counts

4 in All Databases

See more counts

\section{3}

Cited References

View Related Records

Most recently cited by:

Ahmed, I. A.; Asiyanbi-Hammed, T. T.; Idris,

M. A.; et al.

Nutritional perspectives of early Muslims

eating habits.

INTERNATIONAL FOOD RESEARCH

JOURNAL (2017)

Jain, Shilpi; Singh, Arjun; Khare, Puja; et

Toxicity assessment of Bacopa monnieri L. grown in biochar amended extremely

acidic coal mine spoils.

ECOLOGICAL ENGINEERING (2017)

View All

\section{Use in Web of Science}

Web of Science Usage Count

6

Last 180 Days

Learn more

This record is from:

Web of Science Core Collection

- Science Citation Index Expanded

Suggest a correction

If you would like to improve the quality of the data in this record, please suggest a correction. 
Funding

\begin{tabular}{|l|l|}
\hline Funding Agency & Grant Number \\
\hline Ministry of Science, Technology and Innovation (MOSTI) & $06-01-08-S F 0111$ \\
\hline Integrated Centre for Research Animal Care and Use (ICRACU) & \\
\hline Kulliyyah of Allied Health Science, IIUM & \\
\hline
\end{tabular}

View funding text

Publisher

SPRINGER HEIDELBERG, TIERGARTENSTRASSE 17, D-69121 HEIDELBERG, GERMANY

Categories / Classification

Research Areas: Nutrition \& Dietetics

Web of Science Categories: Nutrition \& Dietetics

See more data fields

\section{Cited References: 53}

By: Adebayo, Abiodun Humphrey; Abolaji, Amos Olalekan; Kela, Roseline; et al.

PAKISTAN JOURNAL OF PHARMACEUTICAL SCIENCES Volume: 24 Issue: 4 Pages: 545-551 Published: OCT 2011

2. Inhibition of Acetylcholinesterase Activity and Fe2+-Induced Lipid Peroxidation in Rat Brain In Vitro by Some Citrus Fruit Juices Times Cited: 9 By: Ademosun, Ayokunle O.; Oboh, Ganiyu

JOURNAL OF MEDICINAL FOOD Volume: 15 Issue: 5 Pages: 428-434 Published: MAY 2012

3. Antioxidant activity and phenolic profile of various morphological parts of underutilised Baccaurea angulata fruit

Times Cited: 12

By: Ahmed, Idris Adewale; Mikail, Maryam Abimbola; Bin Ibrahim, Muhammad; et al.

FOOD CHEMISTRY Volume: 172 Pages: 778-787 Published: APR 12015

4. Bridelia ferruginea Promotes Reactive Oxygen Species Detoxification in N-Nitrosodiethylamine-Treated Rats

Times Cited: 2

By: Ajiboye, T. O.; Abdussalam, F. A.; Adeleye, A. O.; et al.

Journal of Dietary Supplements Volume: 10 Issue: 3 Pages: 210-228 Published: SEP 2013

5. Protection against hydrogen peroxide induced oxidative damage in rat erythrocytes by Mangifera indica L. peel extract

Times Cited: 103

By: Ajila, C. M.; Rao, U. J. S. Prasada

FOOD AND CHEMICAL TOXICOLOGY Volume: 46 Issue: 1 Pages: 303-309 Published: JAN 2008

6. Ameliorative effect of Opuntia ficus indica juice on ethanol-induced oxidative stress in rat erythrocytes

Times Cited: 12

By: Alimi, Hichem; Hfaeidh, Najla; Bouoni, Zouhour; et al.

EXPERIMENTAL AND TOXICOLOGIC PATHOLOGY Volume: 65 Issue: 4 Pages: 391-396 Published: MAY 2013

7. Ameliorative effect of ajwain extract on hexachlorocyclohexane-induced lipid peroxidation in rat liver

Times Cited: 16

By: Anilakumar, K. R.; Saritha, V.; Khanum, Farhath; et al.

FOOD AND CHEMICAL TOXICOLOGY Volume: 47 Issue: 2 Pages: 279-282 Published: FEB 2009

8. Oxidative stress: A dead end or a laboratory hypothesis?

Times Cited: 43

By: Azzi, Angelo

BIOCHEMICAL AND BIOPHYSICAL RESEARCH COMMUNICATIONS Volume: 362 Issue: 2 Pages: 230-232 Published: OCT 192007

9. Differential effects of konbu and nori seaweed dietary supplementation on liver glutathione status in normo- and hypercholesterolaemic growing rats 
By: Bocanegra, A; Benedi, J; Sanchez-Muniz, FJ

BRITISH JOURNAL OF NUTRITION Volume: 95 Issue: 4 Pages: 696-702 Published:APR 2006

10. Probucol and cilostazol exert a combinatorial anti-atherogenic effect in cholesterol-fed rabbits

Times Cited: 11

By: Chen, Yulong; Zhao, Sihai; Huang, Bingqiao; et al.

THROMBOSIS RESEARCH Volume: 132 Issue: 5 Pages: 565-571 Published: NOV 2013

11. The possible effect of diets containing fish oil (omega-3) on hematological, biochemical and histopathogical alterations of rabbit Times Cited: 4 liver and kidney.

By: El-Moghazy, M.; Zedan, N. S.; El-Atrsh, A. M.; et al.

Biomedicine \& Preventive Nutrition Volume: 4 Issue: 3 Pages: 371-377 Published: 2014

12. Cardioprotective effect of Cornus mas fruit extract against carbon tetrachloride induced-cardiotoxicity in albino rats

Times Cited: 11

By: Eshaghi, M; Zare, S; Banihabib, N; et al.

J Basic Appl Sci Res Volume: 2 Issue: 11 Pages: 11106-11114 Published: 2012

[Show additional data]

13. Polyphenol antioxidants from natural sources and contribution to health promotion

Times Cited: 4

By: Fasolo, D.; Andrade, J.M.M.

Polyphenols Hum. Health Dis. Volume: 1 Pages: 253-265 Published: 2014

chapter 20

14. Title: [not available]

Times Cited: 1

By: Ford, LD.

2014 hospital compliance manual Published: 2012

Publisher: Orion Publishing Company, London

15. Phytochemical and in vitro antioxidant properties of the methanolic extract of fruits of Blighia sapida, Vitellaria paradoxa and Times Cited: 5 Vitex doniana

By: Hamzah, RU; Egwim, EC; Kabiru, AY; et al.

Oxidants and Antioxidants in Medical Science Volume: 2 Pages: 217-223 Published: 2013

[Show additional data]

16. Curcumin modulation of high fat diet-induced atherosclerosis and steatohepatosis in LDL receptor deficient mice

By: Hasan, S. T.; Zingg, J. -M.; Kwan, P.; et al.

ATHEROSCLEROSIS Volume: 232 Issue: 1 Pages: 40-51 Published: JAN 2014

17. Anticancer and antioxidant effects of extracts from different parts of indigo plant

Times Cited: 18

By: Heo, Buk-Gu; Park, Yun-Jum; Park, Yong-Seo; et al.

INDUSTRIAL CROPS AND PRODUCTS Volume: 56 Pages: 9-16 Published: MAY 2014

18. Sub-chronic toxicological evaluation of the Baccaurea angulata (Belimbing Dayak) fruit juice in rats.

Times Cited: 4

By: Ibrahim, D.; Hazali, N.; Jauhari, N.; et al.

International Journal of Applied Research in Natural Products Volume: 6 Issue: 4 Pages: 23-32 Published: 2013

19. DIETS CONTAINING CORN-OIL, COCONUT OIL AND CHOLESTEROL ALTER VENTRICULAR HYPERTROPHY, DILATION AND FUNCTION TIMES Cited: 18 IN HEARTS OF RATS FED COPPER-DEFICIENT DIETS

By: JENKINS, JE; MEDEIROS, DM

JOURNAL OF NUTRITION Volume: 123 Issue: 6 Pages: 1150-1160 Published: JUN 1993

20. The inhibitory effect of black soybean on hepatic cholesterol accumulation in high cholesterol and high fat diet-induced nonalcoholic fatty liver disease

By: Jung, Ji-Hye; Kim, Hyun-Sook

FOOD AND CHEMICAL TOXICOLOGY Volume: 60 Pages: 404-412 Published: OCT 2013

21. The role of oxidative stress in alterations of hematological parameters and inflammatory markers induced by early hypercholesterolemia

By: Karbiner, Maria Sofia; Sierra, Liliana; Minahk, Carlos; et al.

LIFE SCIENCES Volume: 93 Issue: 15 Pages: 503-508 Published: OCT 102013

22. Low beta-carotene concentrations increase the risk of cardiovascular disease mortality among Finnish men with risk factors 
By: Karppi, J.; Laukkanen, J. A.; Makikallio, T. H.; et al.

NUTRITION METABOLISM AND CARDIOVASCULAR DISEASES Volume: 22 Issue: 10 Pages: 921-928 Published: OCT 2012

23. Protective effect of lactofermented red beetroot juice against aberrant crypt foci formation, genotoxicity of fecal water and

Times Cited: 8 oxidative stress induced by 2-amino-1-methyl-6-phenylimidazo[4,5-b] pyridine in rats model

By: Klewicka, Elzbieta; Nowak, Adriana; Zdunczyk, Zenon; et al.

ENVIRONMENTAL TOXICOLOGY AND PHARMACOLOGY Volume: 34 Issue: 3 Pages: 895-904 Published: NOV 2012

24. Hypercholesterolemia in the rabbit induced by feeding graded amounts of low-level cholesterol - Methodological considerations Times Cited: 101 regarding individual variability in response to dietary cholesterol and development of lesion type

By: Kolodgie, FD; Katocs, AS; Largis, EE; et al.

ARTERIOSCLEROSIS THROMBOSIS AND VASCULAR BIOLOGY Volume: 16 Issue: 12 Pages: 1454-1464 Published: DEC 1996

25. Aqueous extract of Gleditsia sinensis Lam. fruits improves serum and liver lipid profiles and attenuates atherosclerosis in rabbits Times Cited: 21 fed a high-fat diet

By: Lai, Peng; Du, Jun-Rong; Zhang, Meng-Xue; et al.

JOURNAL OF ETHNOPHARMACOLOGY Volume: 137 Issue: 3 Pages: 1061-1066 Published: OCT 112011

26. Hypoglycemic and antioxidative effects of Anac-ardium occidentale Linn

Times Cited: 1

By: Ling, L.

Diabetic rats Published: 2006

Publisher: Universiti Putra Malaysia, Serdang

27. Hypolipemic and antioxidant activities from Tamarindus indica L. pulp fruit extract in hypercholesterolemic hamsters

Times Cited: 86

By: Martinello, F.; Soares, S. M.; Franco, J. J.; et al.

FOOD AND CHEMICAL TOXICOLOGY Volume: 44 Issue: 6 Pages: 810-818 Published: JUN 2006

28. Regulation of oxidative stress and inflammation by hepatic adiponectin receptor 2 in an animal model of nonalcoholic steatohepatitis

Times Cited: 22

By: Matsunami, Tokio; Sato, Yukita; Ariga, Satomi; et al.

INTERNATIONAL JOURNAL OF CLINICAL AND EXPERIMENTAL PATHOLOGY Volume: 3 Issue: 5 Pages: $472-481$ Published: 2010

29. Baccaurea angulata fruit inhibits lipid peroxidation and induces the increase in antioxidant enzyme activities

Times Cited: 3

By: Mikail, Maryam Abimbola; Ahmed, Idris Adewale; Ibrahim, Muhammad; et al.

EUROPEAN JOURNAL OF NUTRITION Volume: 55 Issue: 4 Pages: 1435-1444 Published: JUN 2016

30. Antioxidant Activity of African Medicinal Plants

Times Cited: 5

By: Nafiu, Mikhail Olugbemiro; Salawu, Musa Oyewole; Kazeem, Mutiu Idowu

MEDICINAL PLANT RESEARCH IN AFRICA: PHARMACOLOGY AND CHEMISTRY Book Series: Elsevier Insights Pages: 787-803 Published: 2013

Showing $\mathbf{3 0}$ of $\mathbf{5 3} \quad$ View All in Cited References page 